AL IBTIDA: JURNAL PENDIDIKAN GURU MI (2020) Vol 7 (1) : 19-32

DOI: http://dx.doi.org/ 10.24235/al.ibtida.snj.v7i1.5883

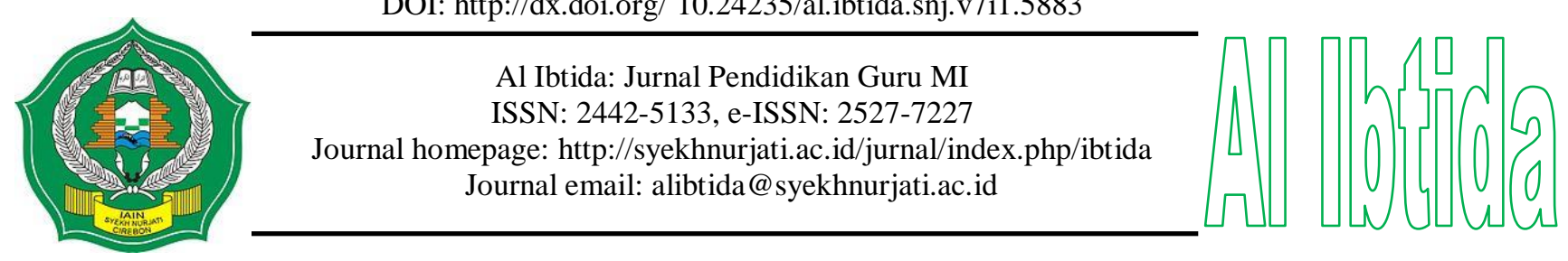

\title{
Integrated STEM through Project Based Learning and Guided Inquiry on Scientific Literacy Abilities in Terms of Self-Efficacy Levels
}

\author{
Hana Lestari* \\ *Department of Madrasah Ibtidaiyah Teacher Education, Faculty of Tarbiyah and Teacher Training, \\ Sahid Entrepreneurial University, Bogor, Indonesia \\ Email: hanalestari3011@gmail.com \\ Ima Rahmawati** \\ **Department of Islamic Education Management, Faculty of Tarbiyah and Teacher Training, \\ Sahid Entrepreneurial University, Bogor, Indonesia \\ Email: dafenta.ima13@gmail.com
}

Received: January $29^{\text {th }}, 2020$. Accepted: April 01 ${ }^{\text {th }}, 2020$. Published: June $07^{\text {th }}, 2020$.

\begin{abstract}
The research aims to describe and find out the different effects between project based learning models and integrated guided inquiry models with STEM (science, technology, engineering, and mathematics) on students' scientific literacy abilities in terms of self-efficacy levels. The study was conducted at Cibatok 1 Elementary School. The subject of this study is with 52 students of fifth grade. The research method was a quasi-experiment method with the-factorial $3 \times 2$ design. Two classes were given treatment, class $\mathrm{V}$-A was given a project based model treatment, while class V-C was given a guided inquiry model treatment. The instruments used consisted of a questionnaire level of self-efficacy and a test of scientific literacy abilities. for measuring validity and reliability. Data analysis was performed with the two-way Anova test. Based on the results of the study, it was found that: (1) there was no difference in the influence of project based learning learning models and guided inquiry on the ability of scientific literacy; (2) there are differences in the ability of scientific literacy among students in high, medium and low levels of self-efficacy; (3) the scientific literacy ability of students with high levels of self-efficacy is better than middle and low levels of self-efficacy; (4) there is an effect of the interaction of learning models with the level of self-efficacy to learn together on students' scientific literacy abilities. The findings of this study are expected to be of practical use for teachers to develop aspects of self-efficacy and students' scientific literacy abilities.
\end{abstract}

Keywords: learning models, scientific literacy ability, self-efficacy, STEM.

\begin{abstract}
Abstrak
Penelitian ini bertujuan untuk mengetahui perbedaan pengaruh pembelajaran dengan model berbasis proyek dan model inkuiri terbimbing terintegrasi STEM (sains, teknologi, teknik, dan matematika) terhadap kemampuan literasi sains siswa ditinjau dari tingkat efikasi diri. Penelitian ini dilaksanakan di Sekolah Dasar Negeri Cibatok 1, dengan subjek penelitian siswa kelas $\mathrm{V}$ yang berjumlah 52 orang. Penelitian ini menggunakan metode quasi eksperimen dengan desain faktorial $3 \mathrm{X} 2$. Terdapat dua
\end{abstract}


kelas yang diberikan perlakuan, kelas $\mathrm{V}$-A diberikan perlakuan model berbasis proyek, sedangkan kelas V-C diberi perlakuan model inkuiri terbimbing. Instrumen yang digunakan terdiri dari angket tingkat efikasi diri dan tes kemampuan literasi sains, instrumen tersebut telah melalui uji validitas dan reliabilitas. Analisis data dilakukan dengan uji Anova dua jalur. Berdasarkan hasil penelitian, ditemukan bahwa: (1) tidak terdapat perbedaan pengaruh model pembelajaran project based learning dan Inkuiri terbimbing terhadap kemampuan literasi sains; (2) terdapat perbedaan kemampuan literasi sains antara siswa dengan tingkat efikasi diri tinggi, sedang dan rendah; (3) kemampuan literasi sains siswa yang tingkat efikasi diri tinggi lebih baik dari tingkat efikasi diri sedang dan rendah; (4) terdapat pengaruh interaksi model pembelajaran dengan tingkat efikasi diri secara bersama-sama terhadap kemampuan literasi sains siswa. Temuan penelitian ini diharapkan dapat digunakan secara praktis bagi guru untuk mengembangkan aspek self-efficacy dan kemampuan literasi sains siswa.

Kata kunci: model pembelajaran, kemampuan literasi sains, efikasi diri, STEM.

\section{INTRODUCTION}

The science learning process provides direct experience to develop student competencies in understanding the environment. Natural science can be defined as three components, namely attitude, processes, and products. Science not only focuse on the concept, but also provide direct experience in developing attitude, processes, and products or more broadly mastering scientific literacy (Jack Holbrook, 2009). The ability of scientific literacy can be explained as the competence to solve problems and make decisions with the knowledge they have, following their level and be able to utilize the technology around them (Gormally et al., 2012).

Scientific literacy is defined as knowledge and understanding of events and events in the surrounding environment (Bell et al., 2003). Science literacy is the ability of someone who uses scientific knowledge to identify problems and draw conclusions based on facts to understand and making decisions through human activities (Becker \& Park, 2011; Liu, 2009). The measurement process of science literacy consists of 3 dimensions, namely content, process and its application. First: Science content refers to the key concepts of things needed to understand natural phenomena and the changes through human activities. Second; the process of science refers to mental processes that involve an answer to a question. Third; the application of science places more emphasis on daily life, as well as applying science in solving real problems such as life and health, the earth and the environment and technology (Turiman et al., 2012).

Science literacy is one of the important abilities needed in digital era. The ability of scientific literacy is one of the competencies must be possessed by students in the 21 st century. Students who have good scientific literacy will build character and behavior by 
forming a mindset to care for and be responsible for themselves, society, and the universe. Students are able to solve problems and make decisions with the knowledge they have following their level and utilize the technology (Bybee et al., 2009).

Science and technology are two interrelated things. Technology supports the development of science in making discoveries and getting explanations about natural phenomena. Analyzing science in a technological context has the potential to increase scientific literacy. One of the efforts that can be done in increasing students' scientific literacy is through the STEM (science, technology, engineering, and mathematics) based learning process (Ceylan \& Ozdilek, 2015). STEM learning is closely related to technology. Technology in the STEM learning process makes it easy for students to explore, discover, and solve problems. It candevelop students' critical thinking abilities, by applying various applications, simulations, software and animations that support the learning process (Daugherty, 2013).

STEM becomes an approach in overcoming problems in the real world by guiding the mindset of students like engineers and scientists. STEM learning guides and trains students to solve problems by building their independence, logical thinking, critical thinking, technological literacy and stimulate them to make decisions for everyday life problems (Han et al., 2016). STEM applies problem-based learning that deliberately places scientific inquiry and the application of mathematics in the context of designing technology as a form of problem-solving. Scientific investigations are rare in technology of education in science classes. But in everyday life, scientific inquiry are routinely applied together as a technical solution to real-world problems (Laboy-Rush, 2011). The application of STEM can be supported by various learning models to improve scientific literacy, one of which is a project based learning model and guided inquiry (Morrison, 2006).

Project based is a learning model that is centered on student activities to develop a mindset in solving problems and making decisions in daily life. Also to provide a meaningful learning experience for students (Alberto et al., 2015; Bell, 2010). Student learning experiences are built from the results produced in the project based learning process. This learning centered on problem-solving by integrating concepts from various components of knowledge from various disciplines (Han et al., 2016).

Project based learning can build students' scientific literacy through problem-solving activities based on information seeking, exploration, interpretation, synthesis, and evaluation of a problem in daily life (Musa et al., 2012). This model can build student literacy through given projects, students are drilled to analyze, discuss, gather information, interpret, and 
assess in working on projects related to what is studied. Thus students can create knowledge about their content and demonstrate their understanding through various forms of representation (Quint \& Condliffe, 2018). Projects train student to be more independence by forming them into teams or in groups and try to formulate ideas. And then reporting project collaboration through group presentations. Projects created can involve a variety of scientific disciplines other than natural science, such as technology, engineering, and mathematics (Bell, 2010). Learning by integrating various disciplines is called STEM based learning. Therefore the project's based learning model can be integrated with STEM to increase students' literacy abilities (Laboy-Rush, 2011).

Another model is guided inquiry learning. It is a learning model in which the teacher provides guidance to students. The guided inquiry learning model provides an opportunity for students to formulate procedures, analyze the results, and draw conclusions independently, while in terms of determining topics, questions, and supporting materials, the teacher is only as a facilitator (Arslan, 2014). This can train students to build answers and think intelligently in finding various alternative solutions to problems raised by the teacher, develop understanding abilities, build a sense of responsibility (individual responsibility), and train the process of delivering the concepts (Douglas \& Chiu, 2012).

The inquiry in the learning process can improve students 'ability to make observations and express answers to a problem through the interpretation of data until a conclusion is reached, to build and practice students' scientific literacy abilities (Carlson, 2008; Gormally et al., 2009). This can be integrated with STEM, because in the investigation process, students collect data consisting of facts involving various scientific and technological disciplines. Through STEM-based guided inquiry, students can build an understanding of solving problems and making decisions (Land, 2013). Learning with the model makes students more focused on learning material related to daily life, students learn independently by finding information from various media by utilizing existing technology to be able to prove the hypothesis that has been set (Becker \& Park, 2011).

Another factor that affects the ability of scientific literacy is self-efficacy which is a belief from within a person about his abilities. Efficacy is a belief of individuals to be able to manage and take the necessary actions to achieve what is desired (Zimmerman \& Schunk, 1993). Self-efficacy is one of the most influential aspects of knowledge about one self in life (Elahi et al., 2011). This is due to the self-efficacy that affects in determining the action to design a goal, including the estimation of various events that will be faced. The abilities possessed by students will make them feel confident in doing the tasks (Ait et al., 2015). 
Research on the relationship and effect of self-efficacy on literacy ability was conducted by (Saribas \& Teksoz, 2014) states that there is a significant correlation between self-efficacy on environmental literacy.

The research results (Tang \& Wei, 2013) shows thatself-efficacy affects the ability of digital literacy. Online distance learning process explained that students who have a high level of efficacy tend to have high digital literacy in terms of information search, selection of digital resources and interest in learning. While research on the relationship of self-efficacy with scientific literacy was conducted by (Ait et al., 2015) as a basic study of self-efficacy in 21 st-century skills. The results of his research stated that student self-efficacy was higher in assessing science for life globally and the lowest in understanding the content and characteristics of scientific knowledge.

Research on self-efficacy to increase scientific literacy has not been done much, but based on several research results (Betthäuser et al., 1970; Haciomeroglu, 2019; Quan \& Elby, 2016), states that there is a connection between understanding science, and the interaction of science understanding. Student's self-efficacy can be seen from, which aspects of students' views of the nature of science linking to daily life supported by each student's self-efficacy. Thus self-efficacy is one of the factors that influence scientific literacy. Scientific literacy is one's ability to understand science both in processes and products. It will build the character of someone for think critically, solve problems, make decisions based on scientific understanding (Quan \& Elby, 2016). Based on this explanation, the scientific literacy ability is influenced by external factors, namely the learning model used and internal factors, namely student self-efficacy. Therefore, this study aims to determine the effect of the project based learning model and the guided inquiry model on the ability of students' scientific.

\section{METHODS}

The research method used was a quasi-experimental method with a $3 \times 2$ factorial design. This study consists of two independent variables (X) namely the learning model (X1) and the level of self-efficacy (X2), and one dependent variable (Y), namely scientific literacy ability. The object of this study is Cibatok 1 Elemantary School, Bogor Regency, in the even semester of the 2018/2019 school year. The population is all fifth-grade students in 4 classes consisting 104 students. Researcher used simple random sampling technique, from the total of 104 students selected into 2 classes namely V A class given project based learning model and $\mathrm{V} \mathrm{C}$ is given guided inquiry learning, 26 students for each classes.

The data in this study is primary data obtained from scientific literacy ability tests and self-efficacy questionnaires. The instrument of scientific literacy ability test and the self- 
efficacy level questionnaire was first tested for validity by asking expert judgment and then tested it on class VI-B. The calculation of the validity of the self-efficacy questionnaire uses the product-moment correlation technique, while the validity of the scientific literacy ability test uses the Item program. While the reliability test was Cronbach Alpha. The data analysis technique was a two-way analysis of variance (ANOVA) with $\alpha=0.05$.

\section{RESULTS AND DISCUSSION}

Differences in the Effects of Project Based Learning and Guided Inquiry Against Students' Literacy Science Ability

For testing the hypothesis in this study using SPSS 22 software related to the 2-way ANOVA test, the following output was obtained:

Table 1. Descriptives Science Literacy with Learning Models

\begin{tabular}{ccccc}
\hline \multicolumn{5}{c}{ Science Literacy } \\
\hline Learning Model & N & Mean & Std. Deviasi & Std. Error \\
\hline Project Based & 21 & 7.29 & 1.384 & .302 \\
Guided Inquiry & 21 & 6.86 & 1.740 & .380 \\
Total & 42 & 7.07 & 1.568 & .242 \\
\hline
\end{tabular}

Table 1 shows that the average of students scientific literacy by the project based learning was 7.29 with std. deviation 1.384 and the average of students scientific literacy with guided inquiry learning by 6,58 with std. deviation 1,740 . From these data, the average of students scientific literacy with project based learning performed better than guided inquiry. However, to determine whether there are significant differences, it can be seen from the significant value in table 2 as follow:

Table 2. The Test among Subjects Effects

Dependent Variable: Science Literacy

\begin{tabular}{lrrrrr}
\hline Source & $\begin{array}{c}\text { Type III Sum } \\
\text { of Squares }\end{array}$ & df & \multicolumn{1}{c}{$\begin{array}{c}\text { Mean } \\
\text { Square }\end{array}$} & \multicolumn{1}{c}{ F } & Sig. \\
\hline Corrected Model & $65.643^{\mathrm{a}}$ & 5 & 13.129 & 13.449 & .000 \\
Intercept & 2100.214 & 1 & 2100.214 & 2151.439 & .000 \\
Learning & 1.929 & 1 & 1.929 & 1.976 & .168 \\
Self-Efficacy & 31.000 & 2 & 15.500 & 15.878 & .000 \\
Learning * Self- & 32.714 & 2 & 16.357 & 16.756 & .000 \\
Efficacy & 35.143 & 36 & .976 & & \\
Error & 2201.000 & 42 & & & \\
Total & 100.786 & 41 & & & \\
Corrected Total & & & & &
\end{tabular}

a. R Squared $=.651$ (Adjusted R Squared $=.603$ )

Table 2 shows that project based learning and the guided inquiry model obtain a significance value $=0.168$, then $0.168>0.05=\alpha$, meaning that $\mathrm{H}_{0}$ is accepted, $\mathrm{H}_{1}$ is rejected 
It means that there is no difference between project based learning and the guided inquiry model of students' scientific literacy abilities. So even though the students who were given the project based learning performed better, the difference was not significant. This is because the application of the two models integrated with STEM approach stimulates students to be more active and creative.

STEM project based learning model trained students to analyze problems related to science and technology, design the projects and assignments to present solutions of the problems identified earlier. It is in line with the opinion of (Laboy-Rush, 2011), stating that through a given project, students are trained to conduct an analysis of problems, explore, gather information, interpretations, and assessments in working on projects related to the problem being examined. Projects given to students train them to be more independence by forming students into teams and formulate ideas and designing presentations. Independence skill of students can be trained by learning in groups to formulate ideas, communicate and find solutions to these problems with the products. Thus through the project based learning model, students can build their content knowledge and demonstrate their understanding through various forms of product designed by utilizing available technology. The explanation illustrates that the STEM project based learning model applied in the classroom influences students' scientific literacy abilities (Becker \& Park, 2011).

Guided inquiry applied in the learning process can improve students' ability to make observations and express the answers to a problem through data interpretation and its conclusion. In line with the opinion of (Douglas \& Chiu, 2012), the guided inquiry learning model provides an opportunity for students to have real and active learning experiences through experiments, they are trained in solving problems while making decisions.

In the classroom implementation, students and teachers have their respective roles in learning with the guided inquiry model. The role of students is to formulate problems and find the solutions through observation or experimentation. The teacher's role in guided inquiry learning is a facilitator and the partner of discussion. This is in line with the opinion of (Douglas \& Chiu, 2012), stating that the guided inquiry model provides an opportunity for students to formulate problems, identify problems, conduct experiments, analyze results, and draw conclusions while the teacher is only as a facilitator. Thus, the guided inquiry learning model can have a positive impact to improve students' scientific activities and abilities. 
The Difference between Science Literacy Abilities between Students with High, Medium, and Low Self-Efficacy

For testing the hypothesis, researcher used SPSS 22 software related to the 2-way ANOVA test for Descriptive Science Literacy in terms of Students' Self-Efficacy Level, the following output was obtained:

Table 3. Descriptive Science Literacy in terms of Students' Self-Efficacy Level

\begin{tabular}{|c|c|c|c|c|c|c|}
\hline & \multirow[b]{2}{*}{$\mathbf{N}$} & \multirow[b]{2}{*}{ Mean } & \multirow{2}{*}{$\begin{array}{c}\text { Std. } \\
\text { Deviation }\end{array}$} & \multirow{2}{*}{$\begin{array}{l}\text { Std. } \\
\text { Error }\end{array}$} & \multicolumn{2}{|c|}{$\begin{array}{l}\text { 95\% Confidence Interval for } \\
\text { Mean }\end{array}$} \\
\hline & & & & & Lower Bound & Upper Bound \\
\hline High & 14 & 8.29 & .726 & .194 & 7.87 & 8.71 \\
\hline Medium & 14 & 6.50 & 1.160 & .310 & 5.83 & 7.17 \\
\hline Low & 14 & 6.43 & 1.869 & .500 & 5.35 & 7.51 \\
\hline Total & 42 & 7.07 & 1.568 & .242 & 6.58 & 7.56 \\
\hline
\end{tabular}

Table 3 shows the average value of students' scientific literacy abilities with a high level of self-efficacy of 8.26 with an std. deviation of 0.726 , the average of scientific literacy of students in the medium level of self-efficacy is 6.50 with std. deviation 1.160, and the average of scientific literacy with low self-efficacy levels are 6.43 with std. deviation 1.869.

From the data, students with high levels of self-efficacy performed better than mmedium and low levels of independence. However, to determine whether there are significant differences, it is shown from the significant value in table 2 "Tests of BetweenSubjects Effects". Obtained a significance value for the level of self-efficacy of 0,000 in table 2 , then $0,000<0.05=\alpha$, means $\mathrm{H}_{0}$ is rejected, $\mathrm{H}_{1}$ is accepted meaning there is a significant difference in scientific literacy abilities between students who have high, medium and low self-efficacy. To analyze the ability of scientific literacy with the difference levels of selfefficacy, do the Tuckey post hock test and get the results in table 4 follows:

Tabel 4. Multiple Comparisons

Dependent Variable: Science Literacy

Tukey HSD

\begin{tabular}{ccccc}
\hline \multicolumn{5}{c}{$\begin{array}{c}\text { Mean } \\
\text { Difference }\end{array}$} \\
\cline { 3 - 4 } (I) Self-Efficacy & (J) Self-Efficacy & $(\mathbf{I}-\mathbf{J})$ & Std. Error & Sig. \\
\hline High & Medium & $1.786^{*}$ & .506 & .003 \\
& Low & $1.857^{*}$ & .506 & .002 \\
Medium & High & $-1.786^{*}$ & .506 & .003 \\
& Low & .071 & .506 & .989 \\
Low & High & $-1.857^{*}$ & .506 & .002 \\
& Medium & -.071 & .506 & .989 \\
\multirow{2}{*}{ *. The mean difference is significant at the 0.05 level. } & & \\
\hline
\end{tabular}


Table 4 shows that there are significant differences between students in high level of self-efficacy with the medium. It can be seen from the acquisition of sig value $0.003<0.05=$ $\alpha$, Beside, there is a difference between students in high with a low level of self-efficacy. It can be seen from the acquisition of sig value $0.002<0.05=\alpha$.

It can be concluded that students' scientific literacy abilities in high self-efficacy levels are better than the medium and low self-efficacy because students who have high self-efficacy can develop scientific literacy abilities well, motivated in the learning process done by students creative and interesting, so the learning process is not only limited to the concept but also the application itself. Self-efficacy is a process in which individuals take initiative with or without the help of others. High self-efficacy requires students to be active and have awareness to learn, know the learning objectives, and determine their strategies. STEM project based learning model, the teacher allows students to discuss in groups ifor planning and continued with discussion. Then, students carry out the project, thus demanding independent students and an attitude of responsibility. After the product is produced, it is evaluated whether it is by the problem to be solved. Products have been evaluated can be represented by the development of existing and adequate technology. This is in line with the opinion of (Gherardini, 2016), a STEM project based learning model involves students directly in learning, the project assigned can be represented through various science and technology-based media, as well as products developed with appropriate techniques and mathematical calculations appropriate so that it can increase student self-efficacy.

Students are guided by the teacher to formulate problems, hypotheses, ask questions and design experiments with the STEM based guided inquiry model. The steps in guided inquiry learning train student independence, so students learn actively and think through experience, students learn actively to build on what they already know, and sthey develop higher thinking through guidance and they learn social interaction with others through teamwork.

While students who have medium and low levels of self-efficacy did not differ significantly in their acquisition of scientific literacy ability scores, this can be seen from the sig value of $0.989>0.05=\alpha$ students in medium and low self-efficacy were more passive in the classroom compared to students with high self-efficacy. When group activities, students with low self-efficacy do not express their opinions or ask questions (Zimmerman \& Schunk, 1993).

According to Khan (2013), self-efficacy can be interpreted as the of students to carry out active learning activities, which are driven by the motive to master a competency that is already owned. Students in low self-efficacy do not have encouragement, motives, and 
willingness to themselves in the learning process. At the time of learning, when the teacher gave projects and experimental activities, students seemed to give up easily when they started working on the project, because they were not motivated to seek information and solutions for the project being worked on. It causes the ability of scientific literacy in students in medium and low levels of self-efficacy does not significant even though the class has implemented active learning.

High self-efficacy will tend to have confidence in difficult tasks, challenging and trying so hard. The task can be done calmly and not worrying while doing the given task. Someone who has high self-efficacy will imagine success in the task that they are doing. This is reflected by the amount of effort done and perseverance in overcoming obstacles. They will continue to do his tasks and not easily to give up and survive. Someone who has low efficacy is easy to give up on tasks in difficult situations, anxious and easily disappointed in carrying out tasks assigned to him (Bandura, 1977; Zimmerman \& Schunk, 1993). The results of this study are supported by research conducted by (Ait et al., 2015), that student of self-efficacy was higher in assessing science for life globally and the lowest in understanding the content and characteristics of scientific knowledge.

\section{The Effect of Interaction between Learning Models with Self-Efficacy on Students' Literacy Abilities}

Table 2 shows that the significance value of the interaction between the learning model with self-efficacy is 0,000 , a value of $0,000<0.05=\alpha$ means reject $\mathrm{H}_{0}$ and $\mathrm{H}_{1}$ are accepted. It means that there is an influence of interaction between learning models with the level of selfefficacy together on students' scientific literacy abilities. The effect of interaction between learning models with self-efficacy together on students' scientific literacy abilities can also be explained from the correlation value ( $\mathrm{r}$ ), which is obtained from the results of the square root $\mathrm{R}$ Squared $=0.651$ of 0.80 which means $80 \%$ of the variation in literacy abilities can be explained by variations in the learning model with self-efficacy. The graph of the interaction between learning models and self-efficacy on students' scientific literacy abilities can be seen in Figure 1. 


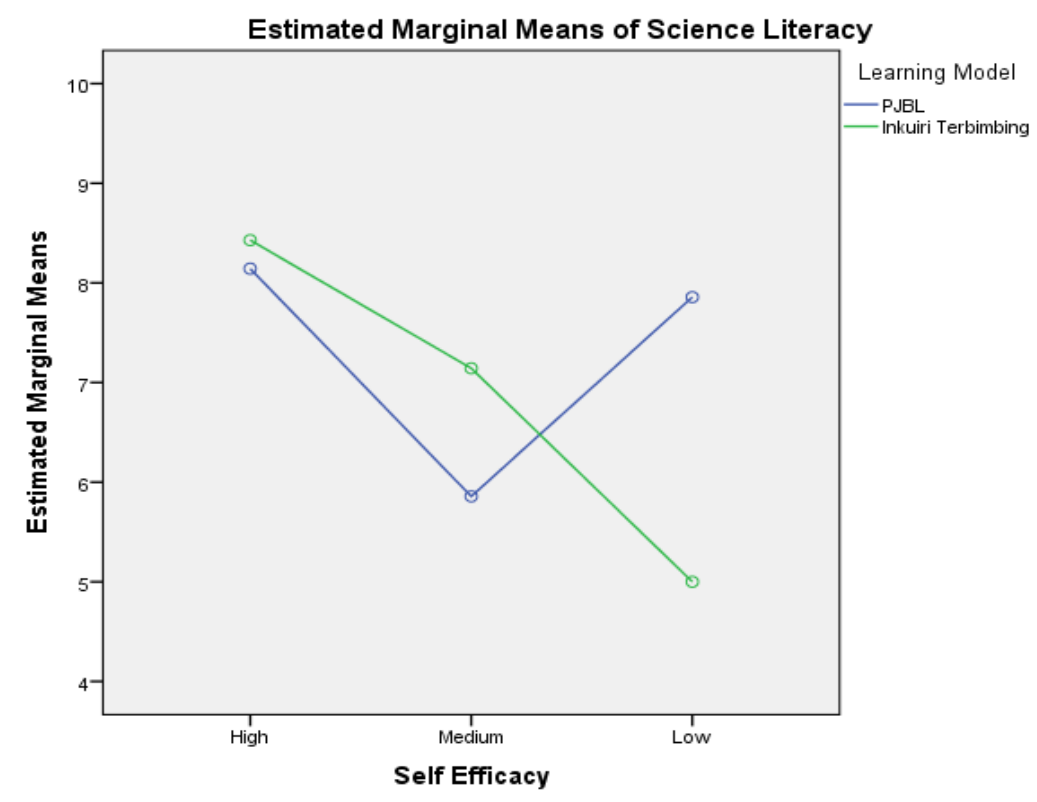

Figure 1. The effect of interaction between learning models and Self-Efficacy

The graph in Figure 1 shows that project based learning in high, medium and low levels of self-efficacy intersects with guided inquiry learning models. It is same with students' scientific literacy abilities. The interaction in this study is the use of project based learning and guided inquiry on the ability of scientific literacy in terms of the level of student selfefficacy.

This is in line with research conducted by Schunk (1985), that there is an interaction between learning models and self-efficacy on students' scientific literacy abilities. The results of his study stated that learning in the classroom with the learning model applied by the teacher can affect students' self-efficacy to learn. During the involvement in the process and assignments, students use self-efficacy to increase learning motivation to gain knowledge and literacy abilities, so that learning achievement can increase. States that self-efficacy significantly increases learning achievement (Yusuf, 2011).

In line with the results of research Elahi et al., (2011), self-efficacy is a significant factor in academic achievement. In the project based learning students are required to play an active role in understanding the material by forming groups to discuss problems that occur in everyday life and solve them, through the products makes students motivated in the learning process, this is also the same as the guided inquiry model, students are trained to build answers and think smart in finding various alternative solutions to the problems that have been formulated in the hypothesis. Students are trained to develop concept understanding abilities, build a sense of responsibility (individual responsibility), and train the process of delivering the concepts found through experiments, so students are motivated in the learning 
process. Students who are motivated in learning will increase their self-efficacy to learn so that they are happy to come up with ideas, design projects and produce products with various forms of representation that are best for solving problems.

\section{CONCLUSION}

Based on finding and discussion, it can be concluded that: (1) there is no difference in the influence of project based learning models and guided inquiry on the ability of scientific literacy, (2) there is a difference in the ability of scientific literacy between students with high, moderate and low levels of self-efficacy, (3) there is a significant difference in scientific literacy abilities between students who have high self-efficacy and moderate self-efficacy, and between students who have a high level of self-efficacy high with a low level of selfefficacy there are also significant differences, (4) there is an influence of the interaction of learning models with the level of self-efficacy together on students' scientific literacy abilities. This study is expected to contribute to the development of education in Indonesia, especially in elementary schools, and to improve knowledge and abilities skills related to scientific literacy. The findings of this study are also expected to be of practical use for teachers to develop aspects of self-efficacy and students' scientific literacy abilities.

\section{REFERENCES}

Ait, K., Rannikmäe, M., Soobard, R., Reiska, P., \& Holbrook, J. (2015). Students' SelfEfficacy and Values Based on A 21st Century Vision of Scientific Literacy - A Pilot Study. Procedia - Social and Behavioral Sciences, 177(July 2014), 491-495. https://doi.org/10.1016/j.sbspro.2015.02.403.

Alberto, J., Gonçalves, P., \& Hess, A. (2015). Creating a Project based Learning Environment to Improve Project Management Skills of Graduate Students. Creating a Project based Learning Environment to Improve Project Management Skills of Graduate Students, 3(2), 120-130. https://doi.org/10.5278/ojs.jpblhe.v0i0.1178.

Arslan, A. (2014). Transition between Open and Guided Inquiry Instruction. Procedia Social and Behavioral Sciences, 141, 407-412. https://doi.org/10.1016/j.sbspro.2014.05.071

Bandura, A. (1977). Self-efficacy: Toward a Unifying Theory of Behavioral Change. 84(2), 191-215.

Becker, K., \& Park, K. (2011). Effects of integrative approaches among science, technology, engineering, and mathematics ( STEM ) subjects on students ' learning: A preliminary meta-analysis. Journal of STEM Education, 12(5), 23-38. https://doi.org/10.1037/a0019454.

Bell, R. L., Blair, L. M., Crawford, B. A., \& Lederman, N. G. (2003). Just do it? Impact of a science apprenticeship program on high school students' understandings of the nature of science and scientific inquiry. Journal of Research in Science Teaching, 40(5), 487-509. https://doi.org/10.1002/tea.10086. 
Bell, S. (2010). Project based Learning for the 21st Century: Skills for the Future. The Clearing House: A Journal of Educational Strategies, Issues and Ideas, 83(2), 3943. https://doi.org/10.1080/00098650903505415.

Betthäuser, B. A., Bourne, M., \& Bukodi, E. (1970). Understanding the Social Mobility Chances of Children from Working-Class Backgrounds in Britain: How Important are Cognitive Ability and Locus of Control ? 1-20.

Bybee, R., McCrae, B., \& Laurie, R. (2009). PISA 2006: An assessment of scientific literacy. Journal of Research in Science Teaching, 46(8), 865-883. https://doi.org/10.1002/tea.20333.

Carlson, J. L. (2008). Effect of Theme-Based, Guided Inquiry Instruction on Science Literacy in Ecology.

Ceylan, S., \& Ozdilek, Z. (2015). Improving a Sample Lesson Plan for Secondary Science Courses within the STEM Education. Procedia - Social and Behavioral Sciences, 177(July 2014), 223-228. https://doi.org/10.1016/j.sbspro.2015.02.395.

Daugherty, M. K. (2013). The Prospect of an "A" in STEM Education. Journal of STEM Education: Innovations and Research, 14(2), 10-15.

Douglas, E. P., \& Chiu, C.-C. (2012). Process-oriented Guided Inquiry Learning in Engineering. Procedia - Social and Behavioral Sciences, 56(Ictlhe), 253-257. https://doi.org/10.1016/j.sbspro.2012.09.652.

Elahi, S., Amrai, K., \& Javad, M. (2011). The relationship between self-efficacy and academic achievement in high school students. Procedia - Social and Behavioral Sciences, 15, 765-768. https://doi.org/10.1016/j.sbspro.2011.03.180.

Gherardini, M. (2016). Pengaruh Metode Pembelajaran Dan Kemampuan Berpikir Kritis Terhadap Kemampuan Literasi Sains. Jurnal Pendidikan Dasar, 7(2), 253. https://doi.org/10.21009/JPD.072.06.

Gormally, C., Brickman, P., \& Lut, M. (2012). Developing a test of scientific literacy skills (TOSLS): Measuring undergraduates' evaluation of scientific information and arguments. CBE Life Sciences Education, 11(4), 364-377. https://doi.org/10.1187/cbe.12-03-0026.

Gormally, C., Brickman, P., Hallar, B., \& Armstrong, N. (2009). Effects of Inquiry-based Learning on Students' Science Literacy Skills and Confidence. International Journal for the Scholarship of Teaching and Learning, 3(2). https://doi.org/10.20429/ijsotl.2009.030216.

Haciomeroglu, G. (2019). The Relationship between Elementary Students 'Achievement Emotions and Sources of Mathematics Self-efficacy To cite this article: The Relationship between Elementary Students 'Achievement Emotions and Sources of Mathematics Self-efficacy.

Han, S., Rosli, R., Capraro, M. M., \& Capraro, R. M. (2016). The effect of Science, technology, engineering and mathematics (STEM) project based learning (PBL) on students' Achievement in four mathematics topics. Journal of Turkish Science Education, 13(Specialissue), 3-30. https://doi.org/10.12973/tused.10168a.

Jack Holbrook, M. R. (2009). The Nature of Science Education for enhancing Scientific Literacy. International Journal of Science Education, 12, 1537-1546. https://doi.org/10.1080/09500690601007549.

Khan, M. (2013). Academic Self-Efficacy , Coping, and Academic Performance in College. 
International Journal Of Undergraduate Research and Creative Activities, 5(October). https://doi.org/http://dx.doi.org/10.7710/2168-0620.1006.

Laboy-Rush, D. (2011). Integrated STEM Education through Project based Learning. Learning. Com,

http://rondoutmar.sharpschool.com/UserFiles/Servers/Server_719363/File/12-

13/STEM/STEM-White-Paper 101207 final[1].pdf

Land, M. H. (2013). Full STEAM ahead: The benefits of integrating the arts into STEM. Procedia Computer Science, 20, 547-552. https://doi.org/10.1016/j.procs.2013.09.317.

Liu, X. (2009). Beyond science literacy: Science and the public. International Journal of Environmental and Science Education, 4(3), 301-311.

Morrison, J. S. (2006). STEM_Articles.pdf(p. 20).

Musa, F., Mufti, N., Latiff, R. A., \& Amin, M. M. (2012). Project based Learning (PjBL): Inculcating Soft Skills in 21st Century Workplace. Procedia - Social and Behavioral Sciences, 59(2006), 565-573. https://doi.org/10.1016/j.sbspro.2012.09.315.

Quan, G. M., \& Elby, A. (2016). Connecting self-efficacy and views about the nature of science in undergraduate research experiences. 020140, 1-14. https://doi.org/10.1103/PhysRevPhysEducRes.12.020140.

Quint, J., \& Condliffe, B. (2018). Project based Learning: A Promising Approach to Improving Student Outcomes. Issue Focus. Mdrc, January. www.mdrc.org.

Saribas, D., \& Teksoz, G. (2014). The Relationship between Environmental Literacy and Selfefficacy Beliefs toward Environmental Education ScienceDirect The relationship between environmental literacy and self-efficacy beliefs toward environmental education. June 2015. https://doi.org/10.1016/j.sbspro.2014.01.820.

Schunk, D. H. (1985). Self-Efficacy And Classroom Learning. Psycology in the Schools, 22(2), 208-223.

Tang, Y., \& Wei, H. (2013). The Journal of Academic Librarianship Distance Learners' Selfef fi cacy and Information Literacy Skills. The Journal of Academic Librarianship, 39(6), 517-521. https://doi.org/10.1016/j.acalib.2013.08.008.

Turiman, P., Omar, J., Daud, A. M., \& Osman, K. (2012). Fostering the 21st Century Skills through Scientific Literacy and Science Process Skills. Procedia - Social and Behavioral Sciences, 59, 110-116. https://doi.org/10.1016/j.sbspro.2012.09.253.

Yusuf, M. (2011). The impact of self-efficacy, achievement motivation , and self- regulated learning strategies on students academic achievement. Procedia - Social and Behavioral Sciences, 15, 2623-2626. https://doi.org/10.1016/j.sbspro.2011.04.158.

Zimmerman, B. J., \& Schunk, D. H. (1993). Albert Bandura: The Man and his Contributions to Educational Psychology Barry J. Zimmerman and Dale H. Schunk. 